\author{
๑А. В. Бойчук ${ }^{1}$, І. М. Нікітіна ${ }^{2}$, В. К. Кондратюк ${ }^{3}$, Н. В. Калашник ${ }^{2}$ \\ ${ }^{1}$ ДВНЗ «Тернопільсъкий державний медичний університет \\ імені І. Я. Горбачевсъкого МОЗ України» \\ ${ }^{2}$ Сулсъкий державний університет \\ ${ }^{3}$ ДУ «Інститут педіатріӥ, акушерства $і$ гінекологї \\ Національної академіӥ медичних наук України», Київ

\section{ПРОФІЛАКТИКА НЕВИНОШУВАННЯ БАГАТОПЛІДНОЇ ВАГІТНОСТІ 3 ВИКОРИСТАННЯМ РОЗВАНТАЖУВАЛЬНОГО АКУШЕРСЬКОГО ПЕСАРІЯ}

\begin{abstract}
Мета дослідження - оцінити есективність застосування розвантажувальних акушерських песаріїв у жінок з багатоплідною вагітністю з високим ризиком невиношування.

Матеріали та методи. Проаналізовано 40 випадків застосування розвантажувальних акушерських песаріїв у вагітних з двійнятами з ознаками невиношування у термінах 18-28 тижнів вагітності, котрі склали першу групу обстежуваних. Друга група - 12 вагітних з двійнятами, котрим був накладений шов на шийку матки з приводу істміко-цервікальної недостатності. Контрольна група - 18 вагітних з двійнею, яким призначалась консервативна терапія. Проведений аналіз перебігу вагітності, пологів, післяпологового періоду та стану неонатальної адаптації в обстежуваних групах.

Результати дослідження та їх обговорення. Динаміка вкорочення шийки матки була значно повільнішою у пацієнток I групи, яким було встановлено розвантажувальний акушерський песарій, це є ефективним методом профрілактики та лікування невиношування у жінок з багатоплідною вагітністю, зниження частоти пізнього аборту та передчасних пологів, перинатальних втрат. Пацієнтки I групи мали меншу кількість випадків передчасного розриву плодових оболонок у 7 (17,5\%) пацієнток I групи порівняно 33 (25,0 \%) жінками II групи та у 5 (27,7 \%) вагітних контрольної групи. В I групі обстежуваних термінові пологи відбулися у 34 (85 \%) випадках, у II групі - у 9 (75,0 \%) випадках, у контрольній - 12 (66,6 \%) випадках. В контрольній групі перинатальні втрати склали 2,7%. В I групі перинатальних втрат не було. При оцінці стану неонатальної адаптації новонароджених обстежуваних груп прослідковується зниження росто-вагових показників у дітей II та контрольної груп, також спостерігається зниження показників оцінки стану новонароджених за шкалою Апгар у II та контрольній групах.

Висновок. Методика застосування розвантажувального акушерського песарія є патогенетично обґрунтованою у вагітних з багатопліддям і дозволяє пролонгувати вагітність до доношеного терміну у 85 \% жінок досліджуваної групи, знизити медикаментозне навантаження на вагітну та плід.
\end{abstract}

Ключові слова: багатоплідна вагітність; невиношування вагітності; розвантажувальний акушерський песарій.

ПРОФИЛАКТИКА НЕВЫНАШИВАНИЯ МНОГОПЛОДНОЙ БЕРЕМЕННОСТИ С ИСПОЛЬЗОВАНИЕМ РАЗГРУЖАЮЩЕГО АКУШЕРСКОГО ПЕССАРИЯ

Цель исследования - оценить эффективность применения разгрузочных акушерских пессариев у женщин с многоплодной беременностью с высоким риском невынашивания.

Материалы и методы. Проанализированы 40 случаев применения разгрузочных акушерских пессариев у беременных с двойней с признаками невынашивания в сроках 18-28 недель беременности, которые составили первую группу обследуемых. Вторая группа - 12 беременных с двойней, которым был наложен шов на шейку матки по поводу истмико-цервикальной недостаточности. Контрольная группа - 18 беременных с двойней, которым назначалась консервативная терапия. Проведен анализ течения беременности, родов, послеродового периода и состояния неонатальной адаптации в обследуемых группах.

Результаты исследования и их обсуждение. Динамика укорочения шейки матки была значительно медленнее у пациенток I группы, которым было установлено разгрузочный акушерский пессарий, это является эсфрективным методом профилактики и лечения невынашивания у женщин с многоплодной беременностью, снижения частоты позднего аборта и преждевременных родов, перинатальных потерь. Пациентки I группы имели меньшее количество случаев преждевременного разрыва околоплодных оболочек у 7 (17,5 \%) пациенток I группы по сравнению с 3 (25,0 \%) женщинами II группы и у 5 (27,7 \%) беременных контрольной группы. В I группе обследуемых срочные роды произошли в 34 (85 \%) случаях, во II группе - в 9 (75,0 \%) случаях, в контрольной - 12 (66,6 \%) случаях. В контрольной группе перинатальные потери составили 2,7 \%. В первой группе перинатальных потерь не было. При оценке состояния неонатальной адаптации новорожденных обследуемых групп прослеживается снижение росто-весовых показателей у детей II и контрольной групп, также наблюдается снижение показателей оценки состояния новорожденных по шкале Апгар во II и контрольной группах.

Вывод. Методика применения разгрузочного акушерского пессария является патогенетически обоснованной у беременных с многоплодием и позволяет пролонгировать беременность до доношенного срока у 85 \% женщин обследуемой группы, снизить медикаментозную нагрузку на беременную и плод.

Ключевые слова: многоплодная беременность; невынашивание беременности; разгружающий акушерский пессарий.

PREVENTION OF MULTIPLE PREGNANCY MISCARRIAGE USING OBSTETRICIAN UNLOADING PESSARY

The aim of the study - to evaluate the effectiveness of the handling of obstetric pessary in women with multiple pregnancies with a high risk of miscarriage.

Materials and Methods. We analyzed 40 cases of handling obstetric pessary in pregnant with twins with symptoms of miscarriage in the period of 18-28 weeks of pregnancy, which constituted the first group of subjects. The second group - 12 pregnant 
with twins, who had imposed a seam on the cervix about cervical incompetence. The control group - 18 pregnant with twins who were prescribed conservative therapy. The above analysis of the flow of pregnancy, childbirth, postpartum and neonatal adaptation state in the surveyed groups.

Results and Discussion. Dynamics of cervical shortening was significantly slower in patients in group I, which was established discharge obstetric pessary, it is an effective method of prevention and treatment of pregnancy loss in women with multiple pregnancies, reduce the frequency of late abortion and preterm birth, perinatal losses. Patients of group I had fewer cases of premature rupture of membranes in $7(17.5 \%)$ patients of group I compared to $3(25.0 \%)$ and group II women in $5(27.7 \%)$ of pregnant control group in I surveyed a group term delivery occurred in $34(85 \%)$ cases in group II $-9(75.0 \%)$ cases in the control group - $12(66.6 \%)$ cases. In the control group, perinatal losses amounted to $2.7 \%$. there were no perinatal losses in the first group. Observed reduction in growth-weights of children in the control group II and also a decrease in newborn state estimation parameters Apgar II and the control group in the assessment of neonatal adaptation newborn surveyed groups.

Conclusions. The method of application handling obstetric pessary is pathogenetically justified in pregnant women with multiple pregnancy and allows to prolong pregnancy to full-term period in $85 \%$ of women surveyed group, medication to reduce the burden on the pregnant woman and fetus.

Key words: multiple pregnancy, miscarriage, unload obstetrican pessary.

ВСтУП. Зростання кількості багатоплідних пологів за останні роки призвело до значного збільшення числа гестаційних ускладнень, підвищення питомої ваги кесарських розтинів, ускладнень у пологах та післяпологовому періоді, підвищення показника перинатальної смертності, порушення процесів неонатальної адаптації новонароджених $[1,2,11]$. Тому пацієнтки 3 багатоплідною вагітністю належать до групи високого ризику перинатальних ускладнень. При багатоплідній вагітності показник перинатальної смертності у п'ять разів перевищує відповідне значення при одноплідній, антенатальна загибель плода у чотири рази вища, а неонатальна смертність $€$ вищою у шість разів $[8,9]$. Основною причиною перинатальної смертності при багатотоплідній вагітності $€$ недоношеність. У більшості випадків самовільне переривання вагітності має повторюваний характер, що свідчить про наявність постійно присутніх фракторів, що провокують такий розвиток подій $[1,2,8]$. Частота передчасних пологів при багатоплідді становить 54,3 \% порівняно 3 9,7\% при одноплідній вагітності [8, 9]. Втрачені вагітності складають майже $17 \%$ від усіх бажаних вагітностей, при цьому 75-80 \% викиднів трапляються на ранніх термінах, i, на жаль, відсутня тенденція до зниження цих показників $[2,10,11]$. Близько половини вагітностей двійнею перериваються до 36 тижнів вагітності. За даними J. Lumley (1993), у Європі $17 \%$ багатоплідних вагітностей перериваються у 20-27 тижнів, $21 \%$ - між 28-м і 31-м тижнями і 17 \% пологів відбуваються між 32 і 36 тижнями. У зв'язку з цим, максимальне пролонгування багатоплідної вагітності $€$ важливою умовою зниження перинатальної захворюваності і смертності у даної групи пацієнток високого ризику. На даний час трансвагінальна ехографрія $€$ практично безальтернативним методом дослідження, що використовується для характеристики шийки матки, дозволяє оцінити довжину шийки матки та стан внутрішнього зіва, маючи переваги над вагінальним пальцевим дослідженням та трансабдомінальною ехограсрією, і $€$ надійним прогностичним критерієм у діагностиці загрози передчасного переривання вагітності $[4,5,9]$.

Доведено, що на сьогодні не існує жодного ефрективного способу профілактики передчасних пологів при багатоплідній вагітності. Перерозтягнення нижнього сегмента матки та надмірний тиск на шийку матки часто спричиняють розвиток істміко-цервікальної недостатності (ІЦН). Сучасні літературні видання недостатньо висвіт- люють проблему застосування розвантажувальних акушерських песаріїв при загрозі переривання багатоплідної вагітності. Порівняльна оцінка використання хірургічного серкляжу та атравматичне застосування розвантажувальних песаріїв довела високу ефективність та певні переваги останніх [3, 7, 12].

Згідно з рандомізованими дослідженнями F. Forester et al. та аналізом літературних джерел можна зробити висновок про рівнозначність цих двох методів лікування ІЦН - хірургічного серкляжу та застосування розвантажувальних акушерських песаріїв. Суттєвою перевагою останніх є простота і доступність методу, можливість уникнення хірургічного втручання та стаціонарного лікування вагітних.

Питання оптимізації антенатального нагляду при багатоплідній вагітності, вибір оптимальних методів лікування і профілактики гестаційних ускладнень, в першу чергу невиношування вагітності, зниження питомої ваги кесарських розтинів, ускладнень у пологах та післяпологовому періоді, зниження показника перинатальної смертності, покращення процесів неонатальної адаптації новонароджених і є предметом даного дослідження.

МЕТА ДОСЛІДЖЕННЯ - оцінити ефективність застосування розвантажувальних акушерських песаріїв у вагітних 3 багатоплідною вагітністю з високим ризиком невиношування.

МАТЕРІАЛИ ТА МЕТОДИ. Наукове дослідження проводилось на базі Сумського обласного клінічного перинатального центру протягом 2015-2016 років. В нього були включені вагітні з дихоріальною діамніотичною двійнею та точно встановленим терміном гестації, що визначався при ультразвуковому обстеженні до 18 тижнів вагітності. Виключенням були пацієнтки з встановленими структурними та хромосомними аномаліями плода, а також 3 монохоріальними двійнятами у зв'язку з високим ризиком розвитку синдрому фрето-фретальної гемотрансфрузії (СФФТ) та можливою необхідністю дострокового розродження. Не включались також пацієнтки при наявності трійні та більшої кількості плодів і за наявності протипоказань до використання розвантажувальних акушерських песаріїв.

Нами проаналізовано 40 випадків застосування розвантажувальних акушерських песаріїв у вагітних 3 дихоріальними двійнятами з ознаками невиношування у термінах 18-28 тижнів вагітності, котрі склали першу групу обстежуваних. До другої групи увійшли 12 вагітних 
з дихоріальними двійнятами, котрим був накладений шов на шийку матки $з$ приводу істміко-цервікальної недостатності. Контрольну групу склали 18 вагітних з дихоріальною діамніотичною двійнею у терміні 18-28 тижнів вагітності, яким проводилась традиційна токолітична терапія 3 приводу загрози невиношування вагітності згідно з діючими клінічними протоколами (наказ МО3 України № 624).

Нами було вивчено загальний, соматичний, акушерсько-гінекологічний анамнез, перебіг вагітності, пологів, динаміку стану шийки матки при прогресуванні багатоплідної вагітності. Крім клінічних методів обстеження та загальноприйнятих лабораторних досліджень, з метою оцінки загрози передчасного переривання вагітності проводилась трансвагінальна цервікометрія, а також оцінка стану шийки матки за Штембергом, де сума балів 5 і вища була показанням до профілактики і лікування загрози переривання вагітності.

Трансвагінальна цервікометрія проводилась за допомогою сучасного ультразвукового апарата «MEDISON» 3 використанням трансвагінального датчика 6,5 МГц, в більш пізні терміни конвексних датчиків 3,5 і 5 МГц у двовимірному ехорежимі відповідно до термінів 10-13 тижнів, 16-22 тижні та 28-34 тижні вагітності. В I триместрі ультразвукова діагностика здійснювалась із застосуванням двох стандартних методик: трансвагінальної ехографрії та трансабдомінального сканування з наповненим сечовим міхуром. Окрім дослідження плідного яйця та екстраембріональних структур, проводилося визначення типу плацентації. Для виконання трансвагінальної цервікометрії вагітну зі звільненим сечовим міхуром вкладали у літотомну позицію. Ультразвуковий датчик вводили в піхву, скеровуючи до переднього склепіння, при цьому намагалися не тиснути на шийку, щоб не спричиняти її штучного видовження. Після отримання сагітального розрізу шийки використовували ехогенну слизову ендоцервіксу для дослідження внутрішнього вічка. Для вимірювання лінійної довжини шийки бігунці розміщували на трикутній ехогенній ділянці зовнішнього вічка та V-подібній виїмці внутрішнього вічка. Кожне обстеження тривало близько 2-3 хв. Основними критеріями загрози переривання вагітності вважали вкорочення шийки матки до 2,0 см і більше, відкриття цервікального каналу на 0,9 см і вище, величина відношення довжини шийки матки до їі діаметра на рівні внутрішнього зіва - 1,16 см.

Песарій виготовлений із біологічно інертного поліетилену. Розробником та виробником акушерських песаріїв $€$ фрірма «Симург», Білорусія. Випускаються вони трьох розмірів. Для нехірургічного серкляжу значно частіше застосовувались песарії другого розміру, що були встановлені 70 \% вагітних. Механізм дії песарія полягає у зменшенні навантаження на шийку матки внаслідок перерозподілу внутрішньоматкового тиску плідного яйця, змиканні шийки матки стінками центрального отвору песарія, фрормуванні вкороченої і частково відкритої шийки та зменшення на неї тиску внаслідок фрізіологічної сакралізації шийки матки й часткової передачі внутрішньоматкового тиску на передню стінку матки, збереження слизової пробки. Показаннями до введення акушерського розвантажувального песарія були: загроза невиношування вагітності у поєднанні з прогресуючими змінами шийки матки у пацієнток з багатоплідною вагітністю, у тому числі після застосування ДРТ, а також пацієнтки з багатопліддям, ко- трі мали в анамнезі викидні на пізніх термінах, передчасні пологи, звичне невиношування вагітності. Враховувались також протипоказання до введення акушерського песарія: рецидивуючі кров'янисті виділення зі статевих шляхів у II-III триместрах вагітності, виражена ІЦН з пролабіюванням плідного міхура та порушенням його цілісності. При запальних захворюваннях піхви, шийки матки, зовнішніх статевих органів проводилась попередня санація інсрекції з подальшим бактеріологічним контролем.

Песарій вводили вагітним у стаціонарі. При спостереженні за жінками після введення песарія проводилось регулярне бактеріологічне дослідження вагінальних мазків, трансвагінальна цервікометрія та контроль розташування песарія кожних 3-4 тижні. В плановому порядку акушерський песарій вилучався в 37 тижнів вагітності або з початком пологової діяльності. Після вилучення песарія проводилась санація статевих шляхів вагінальним гелем «Гінодек» («Юрія-фрарм»), до складу якого входять декаметоксин та гіалуронова кислота, що має антибактеріальні та протизапальні властивості, у тому числі профрілактує післяпологові гнійно-септичні ускладнення.

Статистичну обробку отриманих даних проводили параметричними методами з використанням комп'ютерних статистичних програм [6]. Статистичні дані цитовані з дисертаційної роботи Ірини Миколаївни Нікітіної «Затримка розвитку плода у вагітних, зайнятих у виробництві суперфоссрату (прогнозування, профрілактика та лікування)», захищеної у 2010 році. В дисертаційній роботі дані оброблялися з застосуванням варіаційно-статистичного методу аналізу отриманих результатів за допомогою персонального комп'ютера IBM PC Intel Celeron ${ }^{\mathrm{TM}} 556$ МГц та прикладної програми роботи з електронними таблицями Microsoft $®$ Exel 97 у середовищі Windows Millenium. Статистичну обробку матеріалу проводили методами варіаційної та парної статистики, а також застосовували метод відмінності з використанням t-критерію Стьюдента. Отримані результати вважали достовірними, якщо коефіцієнт достовірності $p$, який знаходили по таблиці Стьюдента, був меншим 0,05.

РЕЗУЛЬТАТИ ДОСЛІДЖЕННЯ ТА ЇХ ОБГОВОРЕНня. Середній вік обстежуваних основної групи складав $(26 \pm 4,2)$ року, вагітних контрольної групи - $(26 \pm 4,5)$ року $(p>0,05)$. За паритетом половина жінок з І групи були першовагітними, решта жінок мали повторні вагітності, з них в 11 - попередні вагітності закінчились нормальними пологами, у 9 - в анамнезі мали місце самовільні викидні та штучні аборти. У 5 (41,6 \%) обстежуваних II групи дана вагітність була першою, решта 7 жінок мали повторні вагітності, причому у 6 (50 \%) - в анамнезі були самовільні викидні та штучні аборти.

При ультразвуковому дослідженні у I триместрі нами визначався тип плацентації у вагітних. Диференційний діагноз моно- і дихоріальної двійні в ранні терміни вагітності ґрунтувався на визначенні кількості плодових яєць, числа ембріонів у плодовому яйці, а також виявленні Табо Ү-ознаки при ретельному дослідженні міжплодової перетинки. Товщина міжплодової перетинки, котра $є$ одним 3 діагностичних критеріїв хоріальності, коливається від 0,8 до 1,1 мм при монохоріальній двійні та від 1,4 мм до 2,8 мм при дихоріальному типі плацентації. У більш пізні терміни вагітності додатковими критеріями типу плацентації служили стать плодів, число плацент, а також відмінності в їх дозріванні (рис. 1). 


\section{Акушерство та гінекологія}
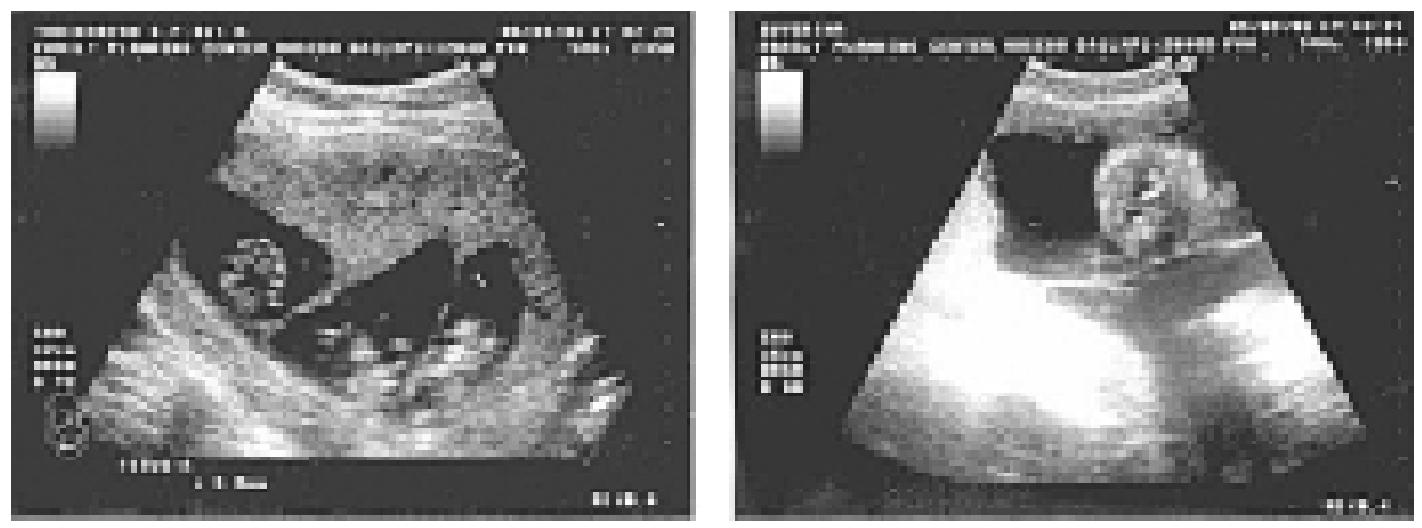

Рис. 1. Ультразвукові маркери хоріальності при багатоплідній вагітності.

При трансвагінальній цервікометрії виявлено, що темпи вкорочення шийки матки при багатоплідній вагітності значно перевищували такі при одноплідній. Так, у 22-24 тижні вагітності в нормі довжина шийки матки при багатоплідній вагітності складала $(33,2 \pm 4,5)$ мм. При загрозі передчасних пологів довжина шийки матки складала $(19 \pm 2,3)$ мм, при цьому зміни шийки матки проявлялися не тільки її укороченням, але й V- або U-подібним розкриттям внутрішнього зіва і цервікального каналу. У пацієнток 3 двійнею довжина шийки матки <19 мм є критерієм ризику «ранніх» передчасних пологів. Цим вагітним проводилась вищезазначена профрілактична терапія загрози передчасних пологів.

Але вже до 22-24 тижнів при багатоплідді зазначалися нижчі показники довжини шийки матки, ніж при одноплідній вагітності: $(27,5 \pm 4,5)$ мм у пацієнток контрольної групи проти $(32,2 \pm 4,9)$ мм у I та $(28,7 \pm 3,7)$ мм у II групі (відмінності статистично не достовірні) порівняно 3 розмірами шийки матки при одноплідній вагітності, що характерні для даного гестаційного терміну $((36,8 \pm 5,2)$ мм). Тобто, як видно з таблиці 1, починаючи 3 цього терміну, темпи укорочення шийки матки при вагітності двійнею значно перевищують у жінок контрольної групи, котрі отримали лише токолітичну терапію. Динаміка вкорочення шийки матки була значно повільнішою у пацієнток I групи, яким було встановлено розвантажувальний акушерський песарій.

Найбільш вираженою різниця в довжині шийки при багатоплідній і одноплідній вагітності відзначалася в III триместрі вагітності. Так, у вагітних I групи в 28-30 тижнів довжина шийки становила $(30,25 \pm 4,1)$ мм, в 31-33 тижні - $(27,2 \pm 4,0)$ мм, в 34-36 тижнів - $(21,8 \pm 3,1)$ мм. До терміну пологів довжина шийки матки у пацієнток з багатопліддям становила $(20,7 \pm 3,9)$ мм проти $(31,6 \pm 3,9)$ мм при одноплідній вагітності. Такі відмінності в довжині шийки матки при багатоплідній і одноплідній вагітності пояснюються різними темпами її вкорочення.

При виявленні патологічного біоценозу піхви проводилась санація вагінальним гелем «Гінодек» («Юрія-фрарм»), що має антибактеріальні та протизапальні властивості, у тому числі профрілактує післяпологові гнійно-септичні ускладнення. Видалення песарія на фоні санації не проводилось. При введенні акушерського песарія у жодної вагітної першої групи не відмічено ускладнень у жодному з випадків, навіть при тривалому використанні песарія протягом 20 тижнів, не відмічено випадків трофрічних ускладнень піхви. У 6 (12,5 \%) вагітних довелося проводити лікування кандидозу піхви до видалення песарія. Токолітична терапія згідно з наказом МОЗ України № 624 проводилась у 13 (32,5 \%) жінок за наявності скарг на болі внизу живота як до, так і після введення песарія.

В I групі обстежуваних термінові пологи відбулися у 34 (85 \%) випадках, у II групі - у 9 (75,0 \%) випадках, у контрольній - 12 (66,6 \%) випадках. Перебіг пологів ускладнився передчасним відходженням навколоплідних вод у 7 (17,5 \%) пацієнток I групи, у 3 (25,0 \%) жінок II групи та у $5(27,7 \%)$ вагітних контрольної групи, безводний проміжок не перевищував $(8,4 \pm 1,5)$ год та $(12,4 \pm 2,3)$ год відповідно $(p<0,05)$. Середня тривалість пологів склала $(10,4 \pm 2,3)$ год у I групі, $(8,6 \pm 1,5)$ год-у II групі та $(9,5 \pm 2,6)$ год - у контрольній групі. Крововтрата в пологах через природні пологові шляхи склала в середньому в жінок I групи

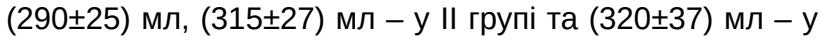
контрольній групі. Патологічної крововтрати під час по-

Таблиця 1. Довжина шийки матки при ультразвуковому дослідженні (мм)

\begin{tabular}{|l|c|c|c|}
\hline \multicolumn{1}{|c|}{ Термін вагітності } & Контрольна група & II група обстежуваних & I група обстежуваних \\
\hline До 15 тижнів & $35,4 \pm 5,6$ & $32,2 \pm 5,43$ & $35,2 \pm 4,3$ \\
\hline $16-18$ тижнів & $34,3 \pm 4,3$ & $31,02 \pm 5,12$ & $34,0 \pm 3,9$ \\
\hline $19-21$ тиждень & $31,3 \pm 3,8$ & $30,9 \pm 5,5$ & $33,3 \pm 4,2$ \\
\hline $22-24$ тижні & $27,5 \pm 4,5$ & $28,7 \pm 3,7$ & $32,2 \pm 4,9$ \\
\hline $25-27$ тижнів & $26,7 \pm 3,6$ & $30,2 \pm 3,5$ & $31,2 \pm 4,5$ \\
\hline $28-30$ тижнів & $25,1 \pm 2,5$ & $28,15 \pm 3,9$ & $30,2 \pm 4,1$ \\
\hline $31-33$ тижні & $23,8 \pm 3,2$ & $25,3 \pm 4,2$ & $27,2 \pm 4,0$ \\
\hline $34-36$ тижнів & $21,4 \pm 3,1$ & $21,6 \pm 4,4$ & $23,8 \pm 3,1$ \\
\hline
\end{tabular}


логів через природні пологові шляхи в обстежуваних групах не було.

Розродження шляхом кесарського розтину було проведено у 7 (17,5 \%) вагітних I групи, у 3 (25,0\%) пацієнток II групи та у 5 (27,7 \%) вагітних контрольної групи. У I групі кесарський розтин проведено у плановому порядку, показанням було тазове передлежання першого плода з двійні. У II групі операція була проведена у плановому порядку у двох випадках, в третьому випадку проведена ургентна операція кесарського розтину з приводу передчасного відшарування плаценти у I періоді пологів. В контрольній групі планові операції були проведені у трьох випадках з приводу тазового передлежання першого плода, у двох наступних випадках був проведений ургентний кесарський розтин з приводу дистресу плода в пологах у терміни 35 та 36 тижнів вагітності.

В контрольній групі при проведенні консервативної токолітичної терапії 18 жінкам передчасні пологи мали місце у 6 (33,3 \%) вагітних, перинатальні втрати склали 2,7 \% (один новонароджений). У 12 вагітних II групи, котрим було проведено хірургічне лікування ІЦН, в одному випадку розвинувся хоріонамніоніт, у зв'язку з цим була призначена антибактеріальна терапія та знятий циркулярний шов, у цієї вагітної пологи відбулися у терміні 28 тижнів та мала місце перинатальна втрата одного новонародженого, що склало 4,1%. В I групі перинатальних втрат не було.

Тривалість перебування в стаціонарі склала в середньому $(12 \pm 1,2)$ дня в жінок I групи, $(18 \pm 1,6)$ дня в II групі та $(21 \pm 1,3)$ дня в обстежуваних контрольної групи $(p<0,05)$.

При вивченні стану неонатальної адаптації новонароджених обстежуваних груп були отримані наступні результати. Середня вага новонароджених I групи склала

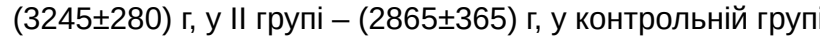
- $(2975 \pm 325)$ г (р>0,05). Оцінка стану новонароджених за шкалою Апгар, відповідно на 1-й та на 5-й хвилинах, була: у новонароджених I групи - $(7,5 \pm 1,4)$ та $(8,4 \pm 1,3)$ бала, в II групі - $(7,3 \pm 1,6)$ та $(8,2 \pm 1,1)$ бала, в контрольній групі - $(7,2 \pm 1,6)$ та $(8,6 \pm 1,2)$ бала (p1-p $2>0,05)$.

ВисновкИ. Таким чином, за результатами проведеного дослідження можна зробити такі висновки:

1. Використання розвантажувального акушерського песарія є ефективним методом профілактики та лікування невиношування у вагітних з багатоплідною вагітністю, зниження частоти пізнього аборту та передчасних пологів, перинатальних втрат за рахунок сумарного впливу, що приводить до змикання та сакралізації шийки матки, перерозподілу тиску плідного яйця, кращого формування вкороченої та частково розкритої шийки матки.

2. Методика застосування розвантажувального акушерського песарія $€$ патогенетично обґрунтованою у вагітних з багатопліддям і дозволяє пролонгувати вагітність до доношеного терміну у 85 \% жінок досліджуваної групи, знизити медикаментозне навантаження на вагітну та плід.

3. Використання розвантажувального акушерського песарія має ряд переваг порівняно з хірургічним серкляжем, зокрема безболісність і простота введення, можливість застосування методу в амбулаторних умовах, економічна доцільність, зниження ризику інфікування і травматизму в пологах.

4. Розвантажувальний акушерський песарій не здійснює негативного впливу на перебіг пологів, зростання числа випадків оперативного розродження та стан здоров'я новонароджених.

ПЕРСПЕКТИВИ ПОДАЛЬШИХ ДОСЛІДЖЕНЬ ПОлягають у поглибленні вивчення проблеми застосування розвантажувального акушерського песарія при монохоріальному типі плацентації з метою профілактики невиношування. Отримані результати показали ефективність застосування розвантажувального акушерського песарія 3 метою профрілактики і лікування невиношування у жінок з багатоплідною вагітністю, попередження розвитку можливих ускладнень під час вагітності, в пологах та перинатальних ускладнень.

\section{СПИСОК ЛІТЕРАТУРИ}

1. Баранов И. И. Перинатальные исходы при многоплодных родах / И. И. Баранов, 3. 3. Токова, А. А. Тадевосян // Акушерство и гинекология. - 2012. - № 1. - С. 98-102.

2. Вдовиченко Ю. П. Багатоплідна вагітність : навч. посіб. Ч. II (для викладача) / ред.: Ю. П. Вдовиченко, Н. Г. Гойда, О. М. Юзько. - К., 2011. - 360 с.

3. Занько С. Н. Предупреждение преждевременных родов с помощью акушерского разгружающего пессария / С. Н. Занько, А. Ю. Журавлев // Здравоохранение. - 2009. - № 8. - C. 6-9.

4. Современные проблемы многоплодной беременности / В. И. Краснопольский, С. В. Новикова, М. В. Капустина [и др.] // Российский вестник акушера-гинеколога. - 2009. № 2. - С. 79-81.

5. Лапач С. Н. Статистические методы в медико-биологических исследованиях с использованием Exel / С. Н. Лапач, А. В. Чубенко, П. Н. Бабич. - К. : Морион, 2000. - 320 с.

6. Михайлова В. В. Опыт использования акушерского разгружающего пессария у женщин с высоким риском преждевременных родов / В. В. Михайлова, Н. К. Рубан,
С. В. Цемашко // Здоровье женщины. - 2008. - Т. 32, № 4. - C. 68-70.

7. Нікітіна І. М. Багатоплідна вагітність : навч. посіб. / І. М. Нікітіна, М. Л. Кузьоменська. - Суми : Університетська книга, 2014. - С. 55-57.

8. Особливості неонатальної адаптації новонароджених $з$ двійні / І. М. Нікітіна, А. Б. Сухарєв, А. В. Бойчук, С. А. Сміян // Журнал клінічних та експериментальних медичних досліджень. - Суми : СумдУ, 2016. - С. 264-271.

9. Spontaneous and non-spontaneous twins: a comparasion study of preterm labor, preterm premature rupture of membranes, gestational age at delivery, maternal age, and length of hospital stay / L. Almonte, M. Davis, C. Ward [et al.] // Twin Research and Human Genetics. - 2012. - Vol. 15, No. 2. - P. 170.

10. The risk of birth defects in dichorionic twins conceived by assisted reproductive technology / T. Kuwata, S. Matusubara, A. Ohkuchi [et al.] // Twin Res. - 2004. - Vol. 7. - P. 223-227.

11. Multicentre controlled trial of cerclage in women at moderate risk of preterm delivery/R. Renaud, P. Lazar, S. Guegun [et al.]//British Journal of Obstetrics and Gynecology. - 2008. - № 91. - P. 731-735. 


\section{REFERENCES}

1. Baranov, I.I., Tokova, Z.Z., \& Tadevosyan, A.A. (2012). Perynatalni yskhody pry mnohoplodnikh rodakh [Perynatal result of multiple pregnancy]. Akusherstvo i ginekologiya - Obstetrics and gynecology, 1, 98-102 [in Russian].

2. Vdovychenko Yu.P. Bahatoplidna vahitnist [Multiple pregnancy]. Kyiv [in Ukrainian].

3. Zanko, S.N., \& Zhuravlev, A.Yu. (2009). Preduprezhdenye prezhdevremennikh rodov s pomoshchyu akusherskogo razhruzhayushcheho pessaryya [Preventing of preterm birth with the help of obstetric off-load pessary]. Zdravokhraneniye Healthcare, 8, 6-9 [in Russian].

4. Krasnopolskiy, V.I., Novikova, S.V., Kapustina, M.V., Titchenko, L.I., Aksenov, A.N., \& Zharova, A.A. (2009). Sovremennye problemy mnohoplodnoy beremennosti [Modern problems of multiple pregnancy]. Rossiyskiy vestnik akusheraginekologa - Russian Reporter of Obstetrician Gynaecologist, 2, 79-81 [in Russian].

5. Lapach, S.N., Chubenko, A.V., \& Babych, P.N. (2000). Statystycheskie metody $v$ medyko-biolohycheskykh issledovanyyakh s ispolzovanyem Exel [Statistical methods in biomedical research using Exel]. Kyiv: Morion [in Russian].

6. Mykhaylova, V.V., Ruban, N.K., \& Tsemashko, S.V. (2008). Opyt ispolzovaniya akusherskogo razhruzhayushchego pessariya u zhenshchyn s vysokym riskom prezhdevremennykh rodov [Experience in the use of obstetric pessary is unloading in women at high risk of preterm birth]. Zdorovye zhenshchiny - Women's Health, 32, 4, 68-70 [in Russian].

7. Nikitina, I.N., \& Kuzomenska, M.L. (2014). Bahatoplidna vahitnist [Multiple pregnancy]. Sumy: Universytetska knyha [in Ukrainian].

8. Nikitina, I.N., Sukharev, A.B., Boychuk, A.V., \& Smiyan, S.A. (2016). Osoblyvosti neonatalnoyi adaptatsii novonarodzhenykh $z$ dviyni [Features of adaptation of neonatal infants from twins]. Zhurnal klinichnykh ta eksperymentalnykh medychnykh doslidzhen - Journal of Clinical and Experimental Medical Research, 4, 2, 264-271 [in Ukrainian].

9. Almonte, L., Davis, M., Ward, C., Brown, D., \& Craparo, F. (2012). Spontaneous and non-spontaneous twins: a comparasion study of preterm labor, preterm premature rupture of membranes, gestational age at delivery, maternal age, and length of hospital stay. Twin Research and Human Genetics, 15, 2, 170.

10. Kuwata, T., Matusubara, S., \& Ohkuchi, A. (2004). The risk of birth defects in dichorionic twins conceived by assisted reproductive technology. Twin Res., 7, 223-227.

11. Renaud, R., Lazar, P., \& Guegun, S. (2008). Multicentre controlled trial of cerclage in women at moderate risk of preterm delivery. British Journal of Obstetrics and Gynecology, 91, 731-735. 